ROCZNIKI TEOLOGICZNE

Volume LXV, issue $10-2018$

Englis h version

DOI: http://dx.doi.org/10.18290/rt.2018.65.10-2en

RENATA MONIKA SIGVA

\title{
A MULTICULTURAL FAMILY. POSITIVE ASPECTS AND DIFFICULTIES
}

\begin{abstract}
The phenomenon of being intercultural or multicultural is a demographic reality resulting from globalization, talent flow, forced migration, and family reunification. Multiculturalism is slowly occurring even in countries that have not historically been receiving a large number of immigrants, such as Poland. The author describes our multicultural families in the aspect of positive sides and disadvantages.
\end{abstract}

Keywords: opportunities; threats; intercultural family; interculturality.

In recent years, political and social changes, the unification of Europe with its idea of open borders, free trade, ubiquitous mobility and the migration of peoples have changed the image of the world and at the same time given birth to new, often difficult challenges for politicians, dissidents, and educators. Contemporary society is not homogeneous and stable, and practically all European countries are now open, therefore multicultural. Contemporary humanity is in the phase of breaking with the rational project of a cohesive, full and purposeful world. Instead, it is going in the direction of a reality that is characterized by heterogeneity, multiplicity and incoherence. It is no longer a process of preparing for multiculturalism and obtaining or learning such cultural diversity. Multiculturalism is now present, and most often its indicators are considered to be measurable and consistent co-existence in a given society made up of different ethnic or cultural groups.

Multiculturalism cannot, however, remain the last link between different cultures, something that should rather be closely arranged into various unique structures existing side by side. The phrase "rather closely" was deli-

Dr. Renata Monika Sigva—Jagiellonian University, Institute of Pedagogy, Department of Education and Care Theory; mailing address: ul. Batorego 12, 31-135 Kraków; e-mail: renata. sigva@uj.edu.pl 
berately used here, because multiculturalism may bring about conflicts, since it does not exclude the isolation of ethnic groups in a given region. We must keep in mind the two-fold meaning of multiculturalism: it is both objective and subjective. The objective sense is contained in the multiplicity and diversity of cultural groups that co-exist and depend on each other in some territorial, political and social space, determined most often by the laws for a polymorphic community's functioning. On the other hand, the subjective meaning of this phenomenon is connected with the existence of a set of psycho-cultural features, beginning with the personality types defined by dominant cultural patterns, through the types of cultural identity, attitudes and orientations towards the dominant values systems, their ideologically shaped attitude towards the fact of diversity, the multiplicity of cultures and the resulting social, political or economic success. ${ }^{1}$

The term "multiculturalism" is the starting point for the analysis performed in this text. Multiculturalism over the last 20 years has become a kind of signum temporis almost all over the world. They understand multiculturalism as a fact of the style of social functioning in many families, whose structure is made up of various cultural hybrids. On the other hand, interculturalism appears as a process of getting to the unique "go-between" when it comes to the functioning of different, culturally heterogeneous families. Interculturalism is understood as taking a step further in relation to multiculturalism. While multi-cultural upbringing may mean assimilating minority groups and including them in the dominant culture, intercultural education presupposes the ability to co-exist, and its long-term goal is integration. ${ }^{2}$

The following text is an attempt to show that interculturalism is a phenomenon with a heterogeneous structure, combining both its positive and negative dimensions. It is an opportunity for multilateral, creative human development from the viewpoint of multiplicity, diversity and mutual acceptance, but it is also a threat in the aspect of building our sense of identity and belonging. The basis for analyzing these opportunities and threats is to explain the concept of "interculturalism," which is not multiculturalism, and we will also point to the family's role in building a cultural identity.

\footnotetext{
1 Tadeusz PALECZNY, Interpersonalne stosunki międzykulturowe (Kraków: Wydawnictwo UJ), 176-177.

${ }^{2}$ Cf. Katarzyna GóRAK-SOSNOwSKA, “Edukacja międzykulturowa a postawy wobec „Innych,” Kwartalnik Kolegium Ekonomiczno-Społecznego. Studia i Prace no 4 (2011-2012).
} 


\section{BEING MULTICULTURAL AND INTERCULTURAL}

In models of contemporary cultural contestations, we find both multicultural and intercultural phenomena, and what is important, they are not the same. Today, researchers point out that the category of multiculturalism first appeared in the United States in the 1940s, when E. Haskell published the work entitled Lance. A Novel about Multicultural Men. In this novel, the reader discovered a new type of American society with features of multiple races, multilingualism and cultural diversity. However, the social idea of multiculturalism mature in the 1960s and 1970s in Canada, followed by the Pacific nations of Australia and New Zealand. ${ }^{3}$

The etymology of the term "multiculturalism" means the multitude of cultures concentrated in a specific social space. In this way, culture becomes a national and ethnic good, with appropriate behavior patterns and their products, created, obtained, used and transformed in the social life process. M. Golka defines multiculturalism as "coexistence in the same space (or the immediate neighborhood without a clear delimitation, or the situation of aspiring to take up the same space) of two or more social groups with different culturally distinctive traits: their external expression, language, behavior, religion, origin, values system, etc., which contribute to the mutual perception of being different with its various consequences." 4

On the other hand, J. Nikitorowicz responds to presenting these matters in the following way:

Multiculturalism understood in this way does not point to dynamics or activity, nor the quantity and quality of the reaction towards Otherness and interactions with Otherness, nor the specific directions and effects of forms of contacts, and thus it does not imply co-operation among the environments or interactions between them, meaning the implementation of civil and universal tasks. We only indicate that multiculturalism is a social phenomenon in the form of the coexistence of dissimilarity, that is, we have an empirical fact. I believe that ever since tribal times, we have always understood multiculturalism in this way; it is a phenomenon characterized by the occurrence of cultural diversity in a given

\footnotetext{
${ }^{3}$ Przemysław P. GRZYBowsKI, Edukacja europejska-od wielokulturowości ku międzykulturowości. Koncepcje edukacji wielokulturowej i międzykulturowej w kontekście europejskim ze szczególnym uwzględnieniem środowiska frankofońskiego (Kraków: Impuls, 2009).

${ }^{4}$ Marian GolkA, "Oblicza wielokulturowości," In U progu wielokulturowości. Nowe oblicza społeczeństwa polskiego, ed. Marian Kempny, Alina Kapciak, Sławomir Łodziński (Warszawa: Oficyna Naukowa, 1997), 55.
} 
territory and different areas. Action is indispensable, as well as noticing Another person, the willingness to understand and cooperate with them. ${ }^{5}$

Indeed, multiculturalism draws attention to the fact that the coexistence of two or more cultural groups is not yet in itself multiculturalism, but only cultural diversity. Researchers point to its characteristic features that can be presented as:

- cultural and ethnic heterogeneity;

- multiplicity of cultural identities;

- awareness of the complexity of interactions between representatives of different cultures;

- various scales of differences not only in terms of the amount of cultural diversity, but also due to their different proportions in many structural forms, where the relationships between its carriers are manifested in different ways. ${ }^{6}$

Worth pointing out is J. Nikitorowicz's interesting position, who, in analyzing multiculturalism, sees this phenomenon not simply as

[...] coexistence in the same space of groups with different cultural traits, but above all as a phenomenon of identity, ideology and education, which allows people to notice and point to new challenges in education in promoting the paradigm of the coexistence of different cultures and creating principles and values for peacefully resolving conflicts.

Furthermore, this researcher points out that

the phenomenon of identity [...] is a person's self-definition of belonging to one or several cultures, recognizing its norms, values and sanctions, as well as anticipating internal conflicts and possible ways to solve them. This ideological phenomenon, or rather being directed by certain norms and values, is describing and undertaking ethical and moral commitments about one's culture and other cultures. It means supporting opinion-forming circles, organizations and associations, creating a foundation for mutual understanding, cooperation, cooperation, and

\footnotetext{
${ }^{5}$ Jerzy NiKiTOROwiCz, "Wielokulturowość-Pogranicze-Człowiek pogranicza. Ku paradygmatowi współistnienia, zachowania i kreowania pokoju” Drohiczyński Przeglad Naukowy. Wielokulturowe Studia Drohiczyńskiego Towarzystwa Naukowego no 6 (2014): 173.

${ }^{6}$ Cf. Andrzej SADOwsKI, “Zróżnicowanie kulturowe a społeczeństwo obywatelskie,” Sprawy Narodowościowe no 14-15 (1999): 31-39; Wojciech BuRszTA, "Wielokulturowość. Pytania pierwsze," in U progu wielokulturowości. Nowe oblicza spoteczeństwa polskiego, edited by Marian Kempny, Alina Kapciak, Sławomir Łodziński (Warszawa: Oficyna Naukowa, 1997).

${ }^{7}$ Jerzy Nikitorowicz, "Ku jakim strategiom w edukacji międzykulturowej w kontekście współczesnych problemów wielokulturowości?” Pogranicze. Studia Społeczne 25 (2015): 28.
} 
upbringing for a peaceful life, which shape and achieve specific ideas related to the implementation of the co-existence paradigm. This educational phenomenon is associated with the creation of an educational system aimed at initiating and implementing intercultural dialogue by creating projects and programs that shape attitudes of openness, understanding and cooperation with other cultures while experiencing cultural differences and being sensitive to them. ${ }^{8}$

There is no doubt that multiculturalism manifests itself through two fundamental values: freedom and equality. Freedom means the possibility of cultivating a chosen culture, and equality is the right of cultures to exist and develop. It is the proliferation of the spheres of freedom and equality that leads to the formation of a multicultural society, and thus causes that our social life has multiple manifestations of what we termed as multiculturalism. ${ }^{9}$

Multiculturalism often gives rise not only to development and getting to know Another person and their culture, but unfortunately, discrimination in the form of intolerance or xenophobia also appears. It is significant that stereotypes are embedded in the awareness of many people, and these are confirmed in real contacts with national, ethnic and other minorities, which may lead to antagonism or even conflicts. It is difficult to disagree with the statement that multiculturalism is a fact in all countries, but "[...] it nevertheless has different signs and there are various ways to possibly implement the educational challenge of interculturalism." ${ }^{10}$ However, multiculturalism should not be identified only and exclusively with the co-occurrence of many cultures, but rather with cultural diversity. Thus, a multicultural society is the result of a state policy that allows realizing an articulated cultural identity.

A. Szahaj rightly points out that there are problems with multiculturalism when it involves fundamentally different cultures. This author points to the dichotomy between Western culture and Islam, the difficulty in the diaspora overcoming issues regarding the equality of men and women, religious tolerance, the separation of religion from the state, and so on. The principle of extreme multiculturalism proclaims the order to respect these mentioned differences and contradictions, and should also result in allowing the appropriate communities to practice their value system. However, this very often conflicts with the legislation in force in a given country.

\footnotetext{
${ }^{8}$ Ibidem, 28-29.

${ }^{9}$ SADOWSKI, "Zróżnicowanie kulturowe a społeczeństwo obywatelskie,” 34-35.

${ }^{10}$ Ewa PAJĄK, "Edukacja międzykulturowa w szkole na przykładzie programu Coverdell World Wise Schools (CWWS) - wyzwania wielokulturowości w Stanach Zjednoczonych i Unii Europejskiej,” in Edukacja ku wartościom, ed. Alicja Szerląg (Kraków: Impuls, 2004), 171.
} 
A. Shahaj stressed that such situations give rise, for example, to the demands for granting Muslim communities in Europe the right for its members to apply the so-called Shariah, which is contrary to Western legislation. ${ }^{11}$ Thus, an important, but also very difficult question arises about the reasons for such multi-culturalism understood literally, whose consequences lead to dichotomous, difficult to reconcile attitudes. This is basically trying to preserve one's cultural tradition while simultaneously ordering one to comply with given standards, including culture, or the gradual departure from one's deeply rooted heritage, so as not to expose oneself to imperialist and colonial allegations.

Interculturalism is the term describing the establishment of relatively stable and dynamic relationships between people of separate cultures. The term appeared in the 1970s in the United States, and later in Quebec, Canada. In the international forum on intercultural relations, it was mentioned for the first time in 1976 during the General UNESCO Conference in Nairobi in the context of the necessity of each contemporary culture to open up to all others. During this period, the intercultural issue also appeared in the framework of the United Nations General Assembly. At the Convention on the Protection and Promotion of the Diversity of Cultural Expressions prepared in 2006, Article 4 defines interculturalism: "[...] the occurrence of different cultures and equal interactions between them, including the possibility of creating common forms of cultural expression through dialogue and mutual respect."12

P.P. Grzybowski notes that, according to Martine Abdallah-Pretceille's theory, the first premises on an intercultural approach to the problems related to cultural diversity appeared in the mid-1960s in Switzerland in the psychological environment. Jean Piaget published an article Nécessité et signification des recherches comparatives en psychologie génétique, which is considered to be the start of intercultural psychology. The sources of intercultural pedagogy in the European cultural circle are mainly works in the field of psychiatry and intercultural psychology and in anthropological studies appearing at the turn of the 1960s an 70s (educational, holistic, cognitive, psychological, symbolic), ethnomethodology, communication theory (especially intercultural communication) and linguistics (interferences and linguistic contacts). ${ }^{13}$ The introduction of the intercultural category, according to

\footnotetext{
${ }^{11}$ Cf. Andrzej SzahaJ, Relatywizm i fundamentalizm oraz inne szkice z filozofii kultury i polityki (Toruń: Wydawnictwo Naukowe UMK, 2008).

${ }^{12}$ Principes directeurs de l unesco pour léducation interculturelle, UNESCO (Paris, 2006), 34.

${ }^{13}$ Przemysław P. GRzYBowski, Edukacja międzykulturowa-konteksty. Od tożsamości po język międzynarodowy (Kraków: Impuls, 2011), 16.
} 
M. Abdallah-Pretceille, allows us to understand culture on three new levels: subjectivist, interactionist and situational. ${ }^{14}$

The first mentioned perspective is a clear dichotomy of the multicultural vision of the world: a meeting, but not among the cultures but only their representatives and about other, personal, original and most importantly separate systems of norms and values. Of course, this includes the process of discovering Another person's cultural dimension, the ability to open up and meet in a dialogue. The interactionist perspective also assumes the presence of two subjects, but here the emphasis is placed on the I dimension, meaning the person who, before he gets to know the Other person and their differences, must define himself according to the way he or she is perceived by representatives of other cultures.

On the other hand, the situational perspective allows us to point out that:

[...] inter-culturalism not only concerns differences as to the main norms and values perceived during an interaction between partners of different cultures. It assumes [...] differences in their positions (statuses), because cultures are always rooted in historical, economic and political factors. This affects the nature of the interactions among actors with a certain cultural identity. Thus, one of the cultures [...] will always be perceived (valued) higher, as the dominant one, and the other will be lower in value, which results in certain consequences in the interpersonal sphere. ${ }^{15}$

As L. Korporowicz noted, interculturalism in the philosophical sense contributes to making a human being a free person who becomes and appears to be not only part of but also a product of the culturally diverse world. In such a world, people get to know and learn about each other, and they begin to enter into the area of their own standards and the cultural values of other groups in a way far from demanding assimilation. ${ }^{16}$ Thus, interculturalism is the interpenetration and exchange of values among different cultures, resulting in the consistent coexistence and cultural competence that contemporary man is equipped with.

The constitutive feature of interculturalism is the characteristic "go-between" located at the meeting point of cultures, but growing out of its unique

\footnotetext{
${ }^{14}$ Por. Przemysław P. GRZYBowsKi, Edukacja europejska-od wielokulturowości ku międzykulturowości. Koncepcje edukacji wielokulturowej i międzykulturowej w kontekście europejskim ze szczególnym uwzględnieniem środowiska frankofońskiego (Kraków: Impuls, 2008).

${ }^{15}$ Ibidem, 49.

${ }^{16}$ Leszek KorPOROwiCz, "Od konfliktu do spotkania kultur, czyli tożsamość jako reguła autotransformacji." In Komunikacja międzykulturowa. Zbliżenia i impresje, ed. Alina Kapciak, Leszek Korporowicz, Andrzej Tyszka (Warszawa: Instytut Kultury, 1995), 31-40.
} 
connector. ${ }^{17}$ Of course, this "go-between" only arises as a consequence of a dialogue thanks to which an individual can strengthen her or his sense of identity, although at the same time they participate in its joint creation through cooperation. Such an attitude may be shaped in a properly set process of being raised in a multicultural society heading towards interculturality. A meeting-point person, in the classical sense of multi-cultural education, is a self-actualizing person who is creatively active and creates his own self-identity. ${ }^{18}$

Unique experiences and living in cultures enables creating people's awareness, including ethnic, religious or national identity. An educated attitude is one that knows, understands, and is interested. This enables understanding not only oneself, but of course others, which is extremely important in intercultural education.

\section{BUILDING IDENTITY IN A MULTI-CULTURAL FAMILY}

The family "is irrevocably bound with the existence of human society and culture," 19 and this takes place through the process of the socialization that shapes a child's personality. This formation means "transferring patterns of behavior, where children search for cultural values and internalize social norms that are accepted and practiced in the life of the family community.",20

The contemporary family is changing at a very fast pace. It is taking on a new face and different forms. At present, completely different models and patterns of family life are present. Families become or are simply multicultural in the sense of co-existing with different people. In the sociological sense, a family is a group of people associated thanks to the marriage relationship and the parents-children relationship. ${ }^{21}$ These two types of social

\footnotetext{
${ }^{17}$ Por. Jerzy NiKitorowicz, "Wartość międzykulturowości," in Edukacja ku wartościom, ed. Alicja Szerląg (Kraków: Impuls, 2004).

${ }^{18}$ Alicja SzERLĄG, "Fenomenologia obcego i jej reperkusje dla edukacji międzykulturowej," in Wielokulturowość-międzykulturowość obszarami edukacyjnych odniesień, ed. Alicja Szerląg (Kraków: Impuls, 2005).

${ }^{19}$ Lucjan KocıK, Rodzina w obliczu wartości i wzorów życia ponowoczesnego świata (Kraków: Wydawnictwo AFM, 2006), 58.

${ }^{20}$ Henryk Cudak, Helena MARzeC, Modele świadomościowe życia rodzinnego deklarowane przez partnerów międzynarodowych małżeństw mieszanych," in Wspótczesna rodzina polska, jej wymiar aksjologiczny i funkcjonowanie, edited by Henryk Cudak, Helena Marzec (Piotrków Trybunalski: Naukowe Wydawnictwo Piotrkowskie, 2001), 74.

${ }^{21}$ Cf. Irena FudAla, "Rodzina wielokulturowa-jaka przyszłość dla Europy i świata?" Drohiczyński Przeglad Naukowy Wielokulturowe Studia Drohiczyńskiego Towarzystwa Naukowego no 6 (2014): 65-92.
} 
relationships that create a family must be based on permanent patterns of behavior and norms that mutually influence family members.

A family is considered to be a social group whose beginnings are set: it simply arises as a result of a marriage bond between a woman and a man. The last element, which speaks of the fact that marriage is composed of people from the opposite sex, presently slowly seems to be outdated. Each family creates its own family identity, and they feel that they are "experiencing self as being someone, and regardless of the changing circumstances, changes in their physical state of being, or changing relationships, they still remain themselves.",22

Human identity has two important aspects, which are the following interpenetrating elements: a sense of belonging and a sense of separateness. The family system separates, regulates and produces these two elements of the process in the course of the process of socialization and upbringing. This means that the family shapes the child's behavior and strengthens her or his sense of identity.

Most of all, a system should respond to the internal changes to the new external situations it is constantly subjected to. An important element in the regulation of these processes is the natural specificity of the family system in the form of two complementary tendencies: constant behavior and change. The ability to maintain a balance between developmental processes (morphogenetic) and tendencies to maintain stability is a key element in maintaining a family system's identity. ${ }^{23}$

In the situation when parents hand on different visions of the world to their child, meaning values and norms, a sense of fear can be created. The family identity usually allows the child to formulate an answer to the question of who she or he is, especially in terms of the values and norms that guide them, including future attitudes or even one's religion. ${ }^{24}$ Shaping an individual's identity is a difficult and complicated process, and it is the internalization of the norms and values of the parents that are responsible for the child's initial stages of development. In the situation of accepting two different cultures, the multiplicity of factors and incentives influences shaping a person's sense of identity: "some lead to bi-culturalism, others to

\footnotetext{
${ }^{22}$ Bogdan DE BARBARO, "Struktura rodziny," in Wprowadzenie do systemowego rozumienia rodziny, ed. Bogdan de Barbaro (Kraków: Wydawnictwo UJ, 1999), 46.

${ }^{23}$ Tomasz BAJKOwsKI, "System rodzinny w przestrzeni międzykulturowej” Pogranicze. Studia Społeczne 30 (2017): 167-180.

${ }^{24}$ Józefa A. Pielkowa, "Wychowanie w rodzinie i jego wartość," Pedagogika Rodziny no 1(4) (2009).
} 
disintegration, renunciation, abandoning one's original identity, or acquiring a negative identity." 25

Contemporary cultural syncretism is normal, and it brings together elements of different, genetically and historically separate cultures. It is a carrier of both hybrid attitudes and hybrid, syncretic identities. A person's identity in this dimension always arises under the influence of the diffusion of various cultural systems that affect an individual's personality. Syncretism has the characteristics of opportunism, and the individual does not try to adapt to the patterns that dominate in a given culture, but to those that are comfortable for them.

One's identity in a multicultural society is heterogeneous, complicated, multi-dimensional, complex and variable. For the proper integration of one's personality and identity, a person who is influenced by different cultures always needs constant reference levels. These are mostly found in the family, tradition, religion, etc. as the basis of their identity. What is significant is that an individual who is looking for such reference points or levels most often goes beyond the boundaries of a homogeneous, monocentric culture, instead choosing to identify with different cultures.

How can we or should we form a person's identity in the light of multiculturalism in the often disrupted inter-cultural circle? People's identities are the unique, unrepeated, separate and specific way that an individual describes their identity, and this is essential. M. Castells points out that a man may have many identities, and this often creates contradictions and somewhat dichotomies in expressing one's self-presentation and in social interactions. When introducing the concept of identity to the social sciences, Erik Erikson defined it as three-dimensional human existence: the body's capabilities and the aspirations and chances of an individual, including the roles and social careers offered by society.

Thus, the author of this concept of identity refers to an individual's identity, but one's psychic strength is the ego, the personal "I" through which we understand ourselves and the surrounding world. Creating one's personal "I" takes place over time and in dialogue with other people, while one's identity is open and never fully completed. However, if it were not for our social identity, there would not be an individual identity, because it gives someone the ability to discern their individual identity. Therefore, a person

\footnotetext{
${ }^{25}$ Jerzy NiKitorowicz, “Typy tożsamości człowieka w społeczeństwie zróżnicowanym kulturowo," Chowanna no 20 (2003): 50-66.
} 
kind of constructs their identity in an individual way, and as M. Castells emphasized, this is reflected in the way society is constituted. ${ }^{26}$

P.V. Hull carried out research in the discussed field. ${ }^{27}$ Bilingual immigrants were asked to complete a personality test. The subjects completed the test twice in both of "their" native languages. The results revealed different personality traits, and depending on the language in which the subjects completed the test, these were completed differently. Thus, parents can completely and unintentionally pass on to their child two extreme visions of the world with the conviction that their views will be internalized by the child. In connection with the above source of conflict between parents, there may also be the question of the religion that a child has accepted. Even if this decision is left to the offspring, at an age when the young person is sufficiently aware of the seriousness and significance of this choice, they may feel torn between different expectations from their parents.

A person's identity is shaped in the process of giving meaning to people, places, and values. If the communication context is complex and the multicultural sphere is wide and multifaceted, then one's identity becomes more dynamic, flexible, and changeable, but at the same time open, vague and ambiguous.

\section{INTERCULTURAL FAMILIES IN POLAND}

L. Korporowicz emphasized the family aspect of interculturalism in his works by pointing out that "the processes of the advancement of various forms of communication and European integration will more and more often confront us with the fact [...] of multicultural families and the multilingualism of socialization, with various manifestations of cultural stress, as well as searching for new forms of cultural and personal identity for individuals in a borderline situation, meaning their multi-nationality and often and discrepancies in identification. ${ }^{, 28}$ In turn, M. Golka writes that interculturalism can be seen "through the number of families in which spouses are of different nationalities, and moreover, their family living in a strange environment."29

\footnotetext{
${ }^{26}$ Por. Manuel CASTELLS, Spoteczeństwo sieci (Warszawa: PWN, 2007).

${ }^{27}$ P.V. Hull, Bilingualism: Two Languages, Two Personalities? Resources in Education, Educational Resources Clearinghouse on Education (Ann Arbor: University of Michigan Press, 1987).

${ }^{28}$ Leszek KorPOROWICZ, "Wielokulturowość a międzykulturowość: od reakcji do interakcji," in U progu wielokulturowości. Nowe oblicza społeczeństwa polskiego, 45.

${ }^{29}$ GOLKA, "Oblicza wielokulturowości," 53.
} 
In the years 2001-2013, nearly 70,000 Poles (both men and women) were registered in marriages with foreigners. In 2013, there were over 3,000 such marriages. ${ }^{30}$ In the case of these couples, we are dealing with the clash of two different cultures, and thus, different values, views, traditions, religions, and languages.

Over the decades, the definition of family and marriage has undergone significant changes. First, the traditional family, then the modern and now the postmodern family's characteristics have changed in terms of gender roles, hierarchy and the realm of family responsibilities. The background of these changes were the cultural and moral changes of particular societies. A unique cultivation and thus the transfer of norms and values takes on a specific form in families where the spouses are characterized by different national affiliations, when they come from different cultures, traditions, values, adopted norms, mother tongues, and even different religions.

In the literature on the subject, we find the term "mixed marriages." This term takes into account the different characteristics of spouses. Thus, we can actually distinguish mixed marriages on the basis of, for example, nationality, race, ethnicity, or religion. In the case of marriages concluded between citizens of different countries, we can talk about binational marriages and cross-border marriages. ${ }^{31}$ These terms highlight the mobility of spouses or their diversity in the context of some features, but it is not uncommon that marriages have more than one mixed feature, not just simply internationality. A totally different, new category should also be mentioned, the multinational families throughout the world. The authors of this term include couples who live in the same place (the same country), but the spouses come from different countries. ${ }^{32}$

Contemporary Polish multicultural or intercultural families are subject to the same processes of all cultural changes caused by contact with different cultural systems, which in turn causes them to transform, evolve, and change. According to the strategies of such a process, we can define these attitudes as follows:

- assimilation based on rejecting cultural identity and taking part in new cultural trends;

\footnotetext{
${ }^{30}$ Sytuacja demograficzna Polski raport 2013-2014 Biuletyn Informacji Publicznej GUS, https://bip.stat.gov.pl (07.11.2017).

${ }^{31}$ Antoni RAJKIEWICZ, "Polskie małżeństwa binacjonalne. Migracje zagraniczne a polityka rodzinna," Biuletyn Rzecznika Praw Obywatelskich 2006, 66.

${ }^{32}$ Ulrich BECK, Elisabeth BECK-GERnSHEIM, Miłość na odległość. Modele życia w epoce globalnej (Warszawa: PWN, 2013).
} 
- separation based on the need to preserve their cultural lifestyle, to defend values and traditions recognized as essential;

- integration based on maintaining contact with new cultural influences, while at the same time maintaining their own authenticity;

- marginalization as a loss of contact with one's own culture, defined as secondary compared to new trends, with ineffective activity in a new culture, often incomprehensible and still foreign. ${ }^{33}$

The functioning of the intercultural family brings with it both a wealth of functioning, developmental opportunities, as well as dilemmas, anxieties and threats.

\section{OPPORTUNITIES AND THREATS IN THE FUNCTIONING OF INTERCULTURAL FAMILIES}

What are the educational opportunities of such intercultural families? The Polish Language Dictionary defines these opportunities as "the possibility of success in some matter or the occurrence of some desired circumstance." ${ }^{34}$ In turn, B. Nowak writes about family opportunities as the possibility of developing an individual's life, educational and social potentials. ${ }^{35}$

An opportunity is to master such social and intrapersonal skills that will help an individual to self-regulate their behavior, in their self-creation and in solving difficult and crisis situations, for example in successfully implementing tasks and developmental dilemmas.

U. Tokarska states that a family's opportunities depend on the level of parental pedagogical culture. This pedagogical culture is, in turn, dependent on external and internal factors. External factors are understood as the social, cultural, environmental or economic situations of caretakers. In turn, the concept of internal factors describes the structure of the family (gender, education, material conditions, interpersonal and intrapersonal relationships). ${ }^{36}$ The notion of opportunities defined in this way assumes the ability to create changes at moments that are important for an individual's development. This means the ability to cope in a crisis situation in the personality dimension, meaning a sense of coherence, which reflects the generalized orientation of the cognitive-evolutionary entity towards the world. ${ }^{37}$

\footnotetext{
${ }^{33}$ Halina GRZYMAŁA-MosZCZYŃSKA, Uchodźcy (Kraków: Zakład Wydawniczy NOMOS, 2000), 17.

${ }^{34}$ Stownik języka polskiego (Warszawa: PWN, 2007).

${ }^{35}$ Beata NowAK, Rodzina w kryzysie. Studium resocjalizacyjne (Warszawa: PWN, 2012).

${ }^{36}$ Urszula TOKARSKA, "Kultura pedagogiczna rodziców," Wychowawca no 1 (2003): 6.

${ }^{37}$ Ibidem, 6.
} 
This orientation consists of intelligibility (the fact that an individual understands the way the environment affects them), controllability (the individual feels competent and has a sense of agency, control) and sensibility (they believe in the purpose of working to improve themselves). An opportunity here is an attitude characterized by activation in the field of undertaking activities, one's sense of agency and awareness in the ability to use their resources.

When these opportunities arise, they determine the influence of the closest environment (education broadly understood). Therefore, an educational opportunity is a situation in which the quantity, quality and type of educational interaction creates the best possible conditions for individual development. This means that one is convinced that their actions (conscious and unintentional) towards a child will trigger changes that the parents want in their child's functioning, both in the immediate environment and in the contemporary world. Therefore, this makes educational success possible, understood as the formation of a mature, self-conscious individual, able to live in society and build healthy relationships and bonds. Such an individual has successfully undergone the process of socialization and has a wellformed system of convictions and values. ${ }^{38}$

In the context of the intercultural family, the best educational opportunity will be taking full advantage of the characteristics of the family environment in which an individual develops and is brought up. Here we should mention once more that the intercultural family is characterized by a variety of influences; in this case, we are dealing with two people who come from different cultural circles. This difference, in turn, is linked with two different traditions, histories, languages, customs, religions and world-worlds, and the child learns about the world in this context. ${ }^{39}$

In connection with living within more than one culture, children learn openness to what is different and strange. J. Nikitorowicz writes that "a family open to contacts with other cultures creatively influences a child." ${ }^{, 40}$ Growing up in the face of two (or more) cultures can create greater openness and increase one's level of tolerance towards a different culture, religion and race. We may also see less vulnerability in adopting stereotypes, and thus a lower level of xenophobic and racist behavior. ${ }^{41}$

\footnotetext{
${ }^{38}$ Cf. Mieczysław ŁOBOCKI, Teoria wychowania w zarysie (Kraków: Impuls, 2008).

${ }^{39}$ CUdAK, MARZEC, "Modele świadomościowe," 23.

40 Jerzy Nikitorowicz, Rodzina wobec wyzwań edukacji międzykulturowej (Białystok: Trans Humana, 1997), 248.

${ }^{41}$ David Matsumoto, Linda JuAng, Psychologia międzykulturowa (Gdańsk: Trans Humana, 2007).
} 
Parents from different cultures raise their children and naturally transmit knowledge about different nations, groups, and traditions. In heterogenic families, through conversations and cultural contexts (e.g. important ceremonies, rituals and customs for the parent), the child gets to know two, often very diverse, cultures. The result may be a child's greater knowledge about the world, thus enrichment through various experiences. We are dealing with either observing or participating in different rituals and customs, but also learning about the history of two different countries and the transmission of cultural heritage. This transmission can take place by oral tradition or by cyclical trips to the country of one's forefathers, the place of a child's family generations.

This significant mobility, openness, flexibility and associated skills of adapting to different cultures and social groups are confirmed by Matsumoto's research, who indicates that children from intercultural families are characterized by greater cultural sensitivity and tolerance. These features seem to condition a lot of information about the world and its many colors and knowledge about the cultural differences that exist in the world. Knowledge, in turn, affects one's flexible openness towards the world. This flexibility in thinking is the main factor that determines the presence of social intelligence. ${ }^{42}$

There are multiple-languages in intercultural families. Children in marriages where the partners use different languages are sometimes bilingual. Usually, each of the parents communicates with their child in their own native language. This, of course, requires each parent to be systematic, especially if the family lives in the country of one of the parents. However, if the family lives in a country that is foreign to the child's parents, they may experience multiple languages. As J. Grzymała-Moszczynska writes: "When I manage to teach my child two languages, they start life with a greater potential, because beyond the obvious ability to efficiently communicate with a larger group of people (in different countries), research conducted on bilingual children points to a higher level of creativity and the ability to think abstractly.,"43

The above point makes it easily for a person to live in our modern, multicultural world. This is because globalization and "popular culture (probably

\footnotetext{
${ }^{42}$ Cf. Dorota WiSzejKo-WIERZBICKA, Kompetencje spoteczne-rozpoznanie i rozwój (Warszawa: Wydawnictwo Wyższej Szkoły Psychologii Społecznej, 2012).

${ }^{43}$ Halina GrZYMAŁA-MoszCZYŃSKA, "Dwie kultury, jedna miłość? Zjawisko związków międzykulturowych," in Cóż wiemy o miłości?, edited by Michał Żebrowski (Kraków: Zakład Wydawniczy NOMOS, 2011).
} 
the version saturated with the American image) operates across borders and continents and disperses national, state, ethnic and linguistic differences." This does not remove the differences completely, and it is always important that at the moral level we be able to adapt more flexibly (while maintaining one's individual identity), being sensitive and careful in relating to different cultures and nations. Taking into account this kind of "tool" when a child from an intercultural family begins his or her life path, there is an increased chance of "getting into" a more elite school and receiving a better education.

Transformation and globalization processes that take place in the modern world may pose a threat to the individual and family in the aspect of a child's upbringing and development. The concept of a threat concerns a kind of mechanism that may cause this phenomenon to no longer be satisfying (meaning a state of satisfying, proper operation) where it is currently located, and it will cease to operate or act less satisfactorily. This change in activity may result from an external situation (here we are talking about an external threat) or from the system itself (when we are talking about an internal threat). ${ }^{45}$

The source of these factors may be social relationships, which conceal the potential possibilities for actions that will be contrary to a good upbringing. The external factors will disorganize or deform these tasks of educating a child and affect the incorrect (or difficult) functioning of the subject of education. Moving further on, an educational threat will be a state that can (as a consequence) lead to disorders in one or more spheres of human life.

A threatening situation is one where the spouses and children will not be able to function as a family in society well enough to be able to grow up and carry out their developmental tasks. This dangerous image of a threat appears as a state that leads to "predicting the loss of values [...] or the desired state of matters." ${ }^{46}$ It should be remembered that every family is a structural and functional part of the general, micro- and macro-system, so all family processes should be perceived in the context of a threat within and outside the family itself.

It seems that the problems of families functioning within different cultures are conditioned by two groups of factors. The first group is the internal structure of the family, its coherence or lack of coherence, and the types of bonds between spouses and children, including communication and dialogue. The second group of factors refers to environmental or external factors, and

\footnotetext{
${ }^{44}$ Zbyszko MELosıK, “Edukacja, młodzież i kultura współczesna,” Chowanna no 20 (2003): 26.

${ }^{45}$ NowaK, Rodzina w kryzysie, 2.

${ }^{46}$ Ibidem, 27.
} 
among these, the influences of the families of origin, local structures and institutions which the family comes into contact seem to be important.

The internal structure of the intercultural family also often breaks down due to the need for its members to migrate. The absence of one of the spouses has consequences on the entire family, and this is conditioned by the duration, purpose, and nature of separation, as well as the quality of relationships and family ties before a migration. The effects of separation include the process of getting used to the social and cultural requirements of the new country in which the migrant resides, and at the same time finding themselves in the situation of a temporarily broken family. ${ }^{47}$ Temporary family disability, unfortunately, can be a difficult test for spouses and children. Threats include weakening family ties, the lack of supervision over children, a disturbed sense of closeness and, finally, often the breakup of the union. The culture of each individual person results from the socialization and upbringing processes he has experienced.

Factors that play an important role in these cultural processes include: language, national origin, religion, family, social class, organization or institution, and the media. Each culture has its own distinct features that become one's personal traits in the internalization process. In the situation of a family with different cultures, these cultural cores do not always facilitate communication among partners, and often they are the sources of frustration and the desire to exert influence and pressure to transfer the learned patterns. The fear of keeping one's personal identity and the need to fight to keep one's own culture from their family of origin also exist.

The children in such mixed marriages are also affected by these matters. The problem of a so-called double identity is already present at the level of identifying with the parents' specific cultural spheres. Even the postulated plans typical of a properly functioning intercultural family, such as appreciating each culture as a potential for making decisions, are sometimes mitigated by tensions and the lack of clearly worded values. This state of uncertainty and conflict causes an intercultural and also intergenerational division. ${ }^{48}$

Another important issue is a failure on the part of generative families of spouses to enter into a relationship and establishing a cross-cultural family. M. Jodłowska-Herudzinska as her first area of analysis noticed the negative reaction on the part of the families of married couples. ${ }^{49}$ The first source of

\footnotetext{
${ }^{47}$ BAJKOWSKI, "System rodzinny," 174.

${ }^{48}$ Cf. ibidem, 176.

${ }^{49}$ Małgorzata JodŁOwSKA-HERUdzIŃSKA, "Kwestie doboru mażeńskiego w międzykulturowych małżeństwach mieszanych, życie rodzinne-uwarunkowania makro i mikrostrukturalne," Roczniki Socjologii Rodziny 14 (2002): 173-189.
} 
such hostilities are the stereotypical, negative ideas about the country or culture of a daughter-in-law or son-in-law. The second source is fear, a kind of fear of not having good contacts with a child, and the inability to have contacts with grandchildren. On the other hand, J. Grzymała-Moszczyńska considers the basis of this fear to be the conviction that a daughter or son will reject their own culture and, consequently, their families. ${ }^{50}$

The families of each of the spouses who choose a partner from a different culture may perceive this union as a kind of betrayal of the values and traditions that are binding in their home and society. All these negative reactions, regardless of the source of origin, may cause a sense of loneliness and rejection on the part of the family, both in spouses and in a child who does not understand the motives of their grandparents. He only sees the effects, meaning the rejection that will project onto the child's development concerning self-acceptance and building one's family identity. However, such attitudes can form not only in a spouse's family. The closest environment of local families may also exhibit racist or xenophobic behavior. Depending on the characteristics of the region or city in which the intercultural family lives, both of these tendencies may appear. Negative reactions on the part of the environment in the form of social rejection or highlighting the child's differences may result in educational and school problems as well as difficulty in establishing contacts and social ties.

Differing values and adopted parental attitudes can cause problems with the cohesive way of raising children as accepted by both parents. In different cultures, the "proper" upbringing of a child takes on different forms. For example, in the United States, a well-behaved child is an independent, ambitious and assertive person. In Japan, a good child will be a person who adapts and is subordinated to the interests of the group (family, society). ${ }^{51} \mathrm{In}$ a family where values, traditions and attitudes collide, it will be more difficult to have one common point of view for raising children, which apart from the positive impact on the child and its development, will also include elements of both pedagogical cultures.

\footnotetext{
${ }^{50}$ GrZYMaŁA-MoszCZYŃSKA, “Dwie kultury, jedna miłość?” 22.

${ }^{51}$ Matsumoto, Juang, Psychologia międzykulturowa, 16.
} 
Based on various opportunities and threats, we can find the foundations of intercultural education, a process that is always present in some culture, and it is the carrier of multidimensional values that encompass its various spheres.

As B. Śliwerski points out, interculturalism, including inter-cultural families, is simply an answer to the reality of a multicultural society. The main goal of the intercultural family's functioning is to preserve and respect the right of people and cultural diversity, as well as the cohabitation for partners without forcing them to live in harmony, but to skillfully resolve the emerging differences or conflicts arising in the background. ${ }^{52}$

In such a family model, there are persistent, basic elements such as tolerance, openness, empathy, and dialogue. The main message of this type of upbringing is being open to contacts with people from other national, ethnic, religious or cultural groups. The process of raising children is aimed at raising their interest in other people and cultures, and then to start to get to know them.

The functioning of intercultural families is more than just learning about other cultures, folklore, languages and religions. It concerns more than just simply school knowledge of who our neighbors are. Above all, it is a workshop involving shaping attitudes and the ability to interact with others. Remember that interculturalism is the result of being monocultural, where regional people are oblivious and isolated, and multiculturalism, which was and is necessary for the need to live "in-between" or on the borderline between two or more cultures. In addition, autonomy in building one's identity dominates. In the individual perspective, this means that we can define our identity based on new categories, such as lifestyle, while in the group perspective, this means negotiating your identity permanently in relation to other groups and their identity projects.

As J. Nikitorowicz wrote, interculturalism is a challenge that contemporary upbringing must face, both in institutions and families ${ }^{53}$ It is also the path the contemporary family will take, and this means the modern approach of being tolerant towards the differences and diversity of cultures and convictions. Intercultural families are now being challenged to function as interactive systems composed of representatives of different cultures, and their

\footnotetext{
${ }^{52}$ Bogdan ŚLIWERSKI, Wspótczesne teorie i nurty wychowania (Kraków: Impuls, 2001), 292.

${ }^{53}$ Jerzy NikitoRowiCz, "Wielopłaszczyznowa i ustawicznie kreująca się tożsamość w społeczeństwie wielokulturowym a edukacja międzykulturowa," in Kultury tradycyjne a kultura globalna. Konteksty edukacji międzykulturowej, ed. Jerzy Nikitorowicz, Mirosław Sobecki, Dorota Misiejuk, vol. 1, (Białystok: Trans Humana, 2001).
} 
actions are not just passive and adaptive. These activities are aimed at mutual learning, meaning getting to know about different areas of values and seeking a common "go-between."

\section{BIBLIOGRAPHY}

BAJKOwSKI, Tomasz. "System rodzinny w przestrzeni międzykulturowej” [The Family System in the Intercultural Space]. Pogranicze. Studia Spoteczne 30 (2017): 167-180.

BARBARo DE, Bogdan. "Struktura rodziny." In Wprowadzenie do systemowego rozumienia rodziny [Family Structure, in: Introduction to a Systemic Understanding of the Family], edited by Bogdan de Barbaro, 46-47. Kraków: Wydawnictwo UJ, 1999.

BeCK, Ulrich, Elisabeth BECK-GernsheIM. Miłość na odległość. Modele życia w epoce globalnej [Love at a Distance. Models of Life in the Global Era]. Warszawa: PWN, 2013.

BurszTA, Wojciech. "Wielokulturowość. Pytania pierwsze." In U progu wielokulturowości. Nowe oblicza spoteczeństwa polskiego [First Questions, in: At the Threshold of Multiculturalism. New Faces of Polish Society], edited by Marian Kempny, Alina Kapciak, Sławomir Łodziński. Warszawa: Oficyna Naukowa, 1997.

Castells, Manuel. Spoteczeństwo sieci [The Network Society]. Warszawa: PWN, 2007.

CuDAK, Henryk, Helena Marzec. "Modele świadomościowe życia rodzinnego deklarowane przez partnerów międzynarodowych małżeństw mieszanych.” In Współczesna rodzina polska, jej wymiar aksjologiczny i funkcjonowanie [Models of Family Life Awareness Declared by Partners of International Mixed Marriages, in: The Contemporary Polish Family, its Axiological Dimension and Functioning,], edited by Henryk Cudak, Helena Marzec, 229-238. Piotrków Trybunalski: Naukowe Wydawnictwo Piotrkowskie, 2001.

FudALA, Irena. "Rodzina wielokulturowa-jaka przyszłość dla Europy i świata?" [The Multicultural Family: What's the Future for Europe and the World?]. Drohiczyński Przeglad Naukowy. Wielokulturowe Studia Drohiczyńskiego Towarzystwa Naukowego no 6 (2014): 65-92.

GolkA, Marian. “Oblicza wielokulturowości.” In U progu wielokulturowości. Nowe oblicza spoteczeństwa polskiego [Faces of Multiculturalism, in: At the Threshold of Multiculturalism], edited by Marian Kempny, Alina Kapciak, Sławomir Łodziński, 55-67. Warszawa: Oficyna Naukowa, 1997.

GóRAK-SOSNOwSKA, Katarzyna. "Edukacja międzykulturowa a postawy wobec „Innych” [Intercultural Education and Attitudes Towards "Others"]. Kwartalnik Kolegium Ekonomiczno-Społecznego. Studia i Prace no 4 (2011-2012): 51-66.

GrzYBowski, Przemysław P. Edukacja europejska-od wielokulturowości ku międzykulturowości. Koncepcje edukacji wielokulturowej i międzykulturowej $w$ kontekście europejskim ze szczególnym uwzględnieniem środowiska frankofońskiego [European Education. From Multiculturalism to Interculturalism. Concepts of Multicultural and Intercultural Education in the European Context, with Particular Reference to the French and Polish Environments]. Kraków: Impuls, 2009.

Grzybowski, Przemysław P. Edukacja międzykulturowa-konteksty. Od tożsamości po język międzynarodowy [An Intercultural Education-Contexts. From One's identity to the International Language]. Kraków: Impuls, 2011. 
GrZYMAŁA-MoszczYŃSKA, Halina. "Dwie kultury, jedna miłość? Zjawisko związków międzykulturowych." In Cóż wiemy o miłości? [Two Cultures, One Love? The Phenomenon of Intercultural Relationships, in: What Do We Know about Love?], edited by Michał Żebrowski. Kraków: Zakład Wydawniczy NOMOS, 2011.

GrzymaŁA-MoszczyŃska, Halina. Uchodźcy [Refugees]. Kraków: Zakład Wydawniczy NOMOS, 2000.

Hull, P.V. Bilingualism: Two Languages, Two Personalities? Resources in Education, Educational Resources Clearing House on Education. Ann Arbor: University of Michigan Press, 1987.

JoDŁowSKA-HERUDZiŃSKA, Małgorzata. "Kwestie doboru mażeńskiego w międzykulturowych małżeństwach mieszanych, życie rodzinne-uwarunkowania makro i mikrostrukturalne [Issues of Marriage Selection in Intercultural Mixed Marriages, Family Life-Macroeconomic and Microstructural Conditions]. Roczniki Socjologii Rodziny 14 (2002): 173-189.

KocIK, Lucjan. Rodzina w obliczu wartości i wzorów życia ponowoczesnego świata [Family in the Face of Values and Life Patterns of the Post-Modern World]. Kraków: Wydawnictwo AFM, 2006.

KORPOROWICZ, Leszek. "Od konfliktu do spotkania kultur, czyli tożsamość jako reguła autotransformacji.” In Komunikacja międzykulturowa. Zbliżenia i impresje [From Conflict to Meeting Cultures, or Identity as a Rule of Autotransformation, in: Intercultural Communication. A Closer Look and Impressions], edited by Alina Kapciak, Leszek Korporowicz, Andrzej Tyszka, 31-40. Warszawa: Instytut Kultury, 1995.

KORPOROWICZ, Leszek. "Wielokulturowość a międzykulturowość: od reakcji do interakcji." In U progu wielokulturowości. Nowe oblicza społeczeństwa polskiego [Multiculturalism and Interculturalism: from Reaction to Interaction, in: At the Threshold of Multiculturalism. New Faces of Polish Society], edited by Marian Kempny, Alina Kapciak, Sławomir Łodziński, 44-65. Warszawa: Oficyna Naukowa, 1997.

KotLARSKA-MichalSKA, Anna. "Małżeństwo jako związek, wspólnota, instytucja, podsystem i rodzaj stosunku społecznego" [Marriage as a Union, Community, Institution, Subsystem and Type of Social Relation]. Roczniki Socjologii Rodziny no 10 (1998): 49-66.

ŁOBOCKI, Mieczysław. Teoria wychowania w zarysie [Theory of Upbringing]. Kraków: Impuls, 2008.

Matsumoto, David, Linda JuAng. Psychologia międzykulturowa [Intercultural Psychology]. Gdańsk: Trans Humana, 2007.

MelosiK, Zbyszko. "Edukacja, młodzież i kultura współczesna" [Education, Youth and Contemporary Culture]. Chowanna no 20 (2003): 26-30.

Nikitorowicz, Jerzy. "Ku jakim strategiom w edukacji międzykulturowej w kontekście współczesnych problemów wielokulturowości?" [Choosing Strategies in Intercultural Education in the Context of Contemporary Problems with Multiculturalism?]. Pogranicze. Studia Spoteczne 25 (2015): 25-40.

Nikitorowicz, Jerzy. Rodzina wobec wyzwań edukacji międzykulturowej [The Family and Intercultural Education Challenges]. Białystok: Trans Humana, 1997.

Nikitorowicz, Jerzy. "Wielokulturowość-Pogranicze-Człowiek pogranicza. Ku paradygmatowi wspólistnienia, zachowania i kreowania pokoju" [Multiculturalism, the Borderland, and the Borderland Man. Towards the Paradigm of Coexistence, Preservation and Creating Peace]. Drohiczyński Przegląd Naukowy. Wielokulturowe Studia Drohiczyńskiego Towarzystwa Naukowego no 6 (2014): 171-191. 
Nikitorowicz, Jerzy. "Typy tożsamości człowieka w społeczeństwie zróżnicowanym kulturowo" [Types of Personal Identity in a Culturally Diversified Society]. Chowanna no 20 (2003): 50-66.

Nikitorowicz, Jerzy. "Wartość międzykulturowości." In Edukacja ku wartościom [The Value of Interculturalness, in: Educating Towards Values], edited by Alicja Szerląg, 83-96. Kraków: Oficyna Wydawnicza „Impuls”, 2004.

Nikitorowicz, Jerzy. "Wielopłaszczyznowa i ustawicznie kreująca się tożsamość w społeczeństwie wielokulturowym a edukacja międzykulturowa." In Kultury tradycyjne a kultura globalna. Konteksty edukacji międzykulturowej [A Multi-Faceted and Constantly Created Identity in a Multicultural Society and Intercultural Education, in: Traditional Cultures and the Global Culture. Contexts of Intercultural Education], edited by Jerzy Nikitorowicz, Mirosław Sobecki, Dorota Misiejuk, vol. 1, 15-35. Białystok: Trans Humana, 2001.

NowaK, Beata. Rodzina w kryzysie. Studium resocjalizacyjne [The Family in Crisis. A Study on Resocialization]. Warszawa: PWN, 2012.

PAJĄK, Ewa. "Edukacja międzykulturowa w szkole na przykładzie programu Coverdell World Wise Schools (CWWS)—wyzwania wielokulturowości w Stanach Zjednoczonych i Unii Europejskiej." In Edukacja ku wartościom [Intercultural Education at Schools Based on the Coverdell World Wise Schools Program (CWWS). Challenges of Multiculturalism in the United States and the European Union, in: Educating Towards Values], edited by Alicja Szerląg, 171-181. Kraków: Impuls, 2004.

PALECZNY, Tadeusz. Interpersonalne stosunki międzykulturowe [Interpersonal Intercultural Relations]. Kraków: Wydawnictwo UJ, 2007.

Pielkowa, Józefa A., "Wychowanie w rodzinie i jego wartość" [Upbringing in a Family and Family Values]. Pedagogika Rodziny no 1(4) (2009).

Principes directeurs de 1 unesco pour 1 éducation interculturelle, UNESCO. Paris, 2006.

RAJKIEWICZ, Antoni. "Polskie małżeństwa binacjonalne. Migracje zagraniczne a polityka rodzinna" [Binational Polish Marriages. Foreign Migrations and Family Politics]. Biuletyn Rzecznika Praw Obywatelskich 2006.

SADOWSKI, Andrzej. "Zróżnicowanie kulturowe a społeczeństwo obywatelskie" [Cultural Diversity and Civil Society]. Sprawy Narodowościowe no 14-15 (1999): 31-39.

SADOWSKI, Andrzej. "Sterowanie wielokulturowością. Dotychczasowe doświadczenia i kierunki przemian (na przykładzie województwa białostockiego)." In Edukacja międzykulturowa w wymiarze instytucjonalnym [Controlling Multiculturalism. Past Experience and Directions of Change (Based on the Example of the Białystok Voivodship), in: Intercultural Education in the Institutional Dimension], edited by Jerzy Nikitorowicz, Mirosław Sobecki, 30-39. Białystok: Trans Humana, 1999.

Stownik języka polskiego [Polish Language Dictionary]. Warszawa: PWN, 2007.

SZAHAJ, Andrzej. Relatywizm i fundamentalizm oraz inne szkice z filozofii kultury i polityki [Relativism, Fundamentalism and Other Sketches from the Philosophy of Culture and Politics]. Toruń: Wydawnictwo Naukowe UMK, 2008.

SZERLĄG, Alicja. "Fenomenologia obcego i jej reperkusje dla edukacji międzykulturowej." In Wielokulturowość - międzykulturowość obszarami edukacyjnych odniesień [Phenomenology of a Foreigner and its Repercussions on Intercultural Education. In: Multi-Cultural References to Intercultural Educational Areas], edited by Alicja Szerląg. Kraków: Impuls, 2005. 
ŚLIWERSKI, Bogusław. Wspótczesne teorie i nurty wychowania [Contemporary Theories and Educational Trends]. Kraków: Impuls, 2001.

TOKARSKA, Urszula. "Kultura pedagogiczna rodziców" [Parental Pedagogical Culture], Wychowawca no 1 (2003): 5-6.

WisZeJKo-WIERZBICKA, Dorota. Kompetencje społeczne-rozpoznanie i rozwój [Social Competencies, Identification and Development]. Warszawa: Wydawnictwo Wyższej Szkoły Psychologii Społecznej, 2012.

\section{Translated by Jan Kobytecki}

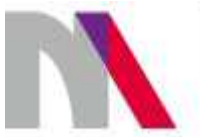

The preparation of the English version of Roczniki Teologiczne (Annals of Theology) and its publication in electronic databases was financed under contract no. 836/P-DUN/2018 from the resources of the Minister of Science and Higher Education for the popularization of science. 